\title{
機械学習とユーザ知識を用いたイベント情報の構 造化
}

\section{Extraction of Structured Information by Machine Learning Using Community Information}

\begin{tabular}{|c|c|}
\hline $\begin{array}{l}\text { 森近 憲行 } \\
\text { Noriyuki Morichika }\end{array}$ & $\begin{array}{l}\text { 東京大学大学院工学系研究科 } \\
\text { School of Engineering, The University of Tokyo } \\
\text { tt106878@mail.ecc.u-tokyo.ac.jp }\end{array}$ \\
\hline $\begin{array}{l}\text { 濱崎 雅弓 } \\
\text { Masahiro Hamasaki }\end{array}$ & $\begin{array}{l}\text { 産業技術総合研究所 } \\
\text { National Institute of Advanced Industrial Science and Technology } \\
\text { hamasaki@ni.aist.go.jp，http://staff.aist.go.jp/masahiro.hamasaki/ }\end{array}$ \\
\hline 龟田 老宙 & $\begin{array}{l}\text { 東京大学大学院情報理工学系研究科 } \\
\text { Graduate School of Information Science and Technology, The University of Tokyo } \\
\text { kameda@nii.ac.jp，http://cyprus.ex.nii.ac.jp/ kameda/ }\end{array}$ \\
\hline 大kki Ohmukai & $\begin{array}{l}\text { 国立情報学研究所 } \\
\text { National Institute of Informatics } \\
i 2 \mathrm{k} \text { @ii.ac.jp，http://www.research.nii.ac.jp/ i2k/ }\end{array}$ \\
\hline $\begin{array}{l}\text { 武田 英明 } \\
\text { Hideaki Takeda }\end{array}$ & 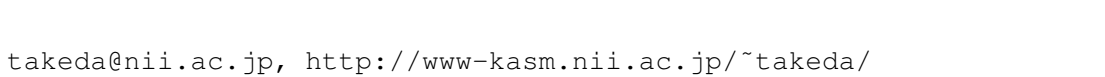 \\
\hline
\end{tabular}

keywords: information extraction, machine learning, collective intelligence

\section{Summary}

In this paper, we describe our approach for information extraction from documents, which is based on supervised machine learning and collective intelligence approach. This approach is aimed at redeeming each method, because each method has merits and demerits. It provides various ways for users to input data to improve information extraction. Users can add not only supervised data but also a rule to extract values for a set of attributes. Various ways to input data allows many users to add a lot of data for quality improvement and machine learning can reduce noise of data input by users. We implemented it in event-information extraction system, and the experimental result shows effectiveness in correctness and convenience.

\section{1. は じめに}

ウェブの普及に伴って , ウェブ上には膨大なドキュメン トか蓄積されてきている .これらのドキュメントはHTML というマークアップ言語の文法に沿って記述されるが， HTML による記述は段落の構成やフォントの指定など， 人間が产の内容を理解しやすいようにするものが多い. このように, 現在のウェブは人か読むことを中心に構成 されていることから, プログラムなどでウェブ上のドキュ メントを, 記述されている内容を考慮して大量に処理す ることが難しいという問題がある .これらのドキュメン 卜を機械可読なものとするためには, 情報抽出を行って 構造化されたドキュメントに変換する必要がある．

従来から研究がおこなわれている情報抽出の手法とし ては, 人手で抽出規則を作成し抽出を行う方法や機械学 習などの方法で抽出規則を自動作成し抽出を行う方法が ある [Xin 08, 佐藤 95] . これらの方法には光れ光れ高い 抽出精度が実現可能, 一度分類器を構築してしまえば光
れ以降保守の必要性はあまりない, という利点がある．し かし一方で，前者には膨大な抽出規則を作成する必要が ある，後者には良い精度で抽出を行うためには事前にた くさんの教師データを用意する必要がある，という欠点

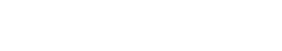

一方で，集合知を利用したアプローチも注目されてい る. 集合知とは多樣性, 独立性, 分散性, 集約性のある 多数の人々が参加することによって個々人の知識だけで は得られない正しい知識が得られるというものである [Surowiecki 05] . Web 2.0 とはこのような集合知を活用 する新しいWeb の利用形態であり，2000 年代中頃から 注目されるようになった [O'REILLY 05] . 典型的なサー ビスとしては多数の著者が参加して作られるオンライン 百科事典である Wikipedia*1や多数の人々がタグを共有 するソーシャルタギングサービスである deli.cio.us ${ }^{* 2}$ が ある．また，より実験的な試みとしてはソーシャルタギ

\footnotetext{
*1 http://www.wikipedia.org/

$* 2$ http://delicious.com/
} 
ングサービスにおけるタグ・ユーザ・URL の関係からオ ントロジーを構成するという研究 [Mika 05]や，音声認 識の結果をユーザに開示することでユーザ認識誤りを訂 正する協力をしてもらい，光の訂正データを機械学習に 用いることで音声認識性能を向上させる方法 [後藤 10] どがある．このように現在ではタグから文章，誤り訂正 まで樣々なレベルでのユーザの参画による Web 上の活動 が行われている.

乥こで我々は，機械学習による抽出とシステム利用者 の集合知を組み合わせた情報抽出手法を提案する．我々 の提案する情報抽出手法では，多樣なユーザ入力，具体 的には段階的な情報抽出と各段階でのユーザ入力を用意 することで，より多くの知識を集めることができる

本稿では, 我々の提案手法を実装したイベント情報構 造化システムを用いて，提案手法の評価について検討す る . 被験者実験では，用意したさまざまなユーザ参加の 負荷の大きさを計測し，本提案手法の有効性を示す．

以下, 2 章て情報抽出の先行研究について述へ， 3 章で 提案手法について，4 章でイベント情報を対象に実装し たシステムについて説明し，5章で被験者実験と关の結 果，考察について議論する．最後に，6 章で本稿のまと めと今後の課題について述べる .

\section{2. 関 連 研 究}

テキストからの情報抽出に関する研究は, 以前から多 く行われている．関根らは情報抽出の代表的な要素技術 として , パターンマッチングによる抽出や，固有表現抽 出技術を挙げている [関根 99].

本研究で対象とする，属性情報抽出でも多くの研究が なされている，属性情報抽出の方法として，人手で抽出 規則を作成し光れをドキュメントに適用する方法と [佐 藤 95, 三宅 02]，機械学習などの手法を用いて抽出規則 を自動で生成し，弚れをドキュメントに適用する方法が ある [Xin 08, 吉谷 04] .

佐藤らは, 会議告知記事, 論文募集記事が扱われる二 ユースグループの日本語記事，英語記事产れ光れに対し て，人手で作成した抽出規則を適用することで，ダイジェ ストを自動生成するシステムを構築した [佐藤 95] . 佐藤 らが作成した抽出規則は，

1.センタリング，箇条書きなどの表示のスタイル

2. 抽出する情報に特有な言語パターン

に基づいてダイジェストを作成するために記事からタ イトル，開催期日，開催場所，(論文募集記事ならば) 論文 募集締切期日を抽出するものであり，日本語記事の未知 データで約 $60 \%$ ，英語記事で約 50 \% と高い抽出精度を 実現している。このように, 人手で抽出規則を作成する 手法では，高い精度での情報抽出を実現できる．しかし， 高い精度を実現するためには膨大な量の抽出規則を人手 で作成しなければならないというデメリットもある．さ らに，抽出規則を作成するのに用いられたスタイル情報

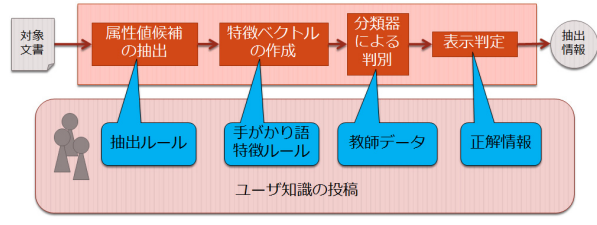

図 1 情報抽出の流れ

や言語パターンというものは, 時間が経過するにつれて 変化, 多樣化する可能性もある.このように, 人手で抽 出規則を作成するという方法では，高い精度を実現でき る一方で, 弚のためには延々と抽出規則を作成し続ける 労力を , システムの管理者などが負わなければならない .

また，Xin らは，学会ホームページのオントロジーを 作成し，機械学習を用いて情報を構造化するセマンティッ ク・カンファレンス・カレンダーシステムを構築した [Xin 08] . 機械学習による情報抽出であれば抽出規則は学習に より得られるので, 弚の作成にあまり大きな労力はかか らない．しかし，人手によって作成された情報抽出規則 による抽出よりも精度は下がってしまう傾向にある．Xin らはサポートベクトルマシン (SVM)や，条件付き確率 場 (CRF) を改良した Hierarchical Conditional Random Fields(HCRF)など，複数の機械学習手法を用いて情報抽 出の精度を考察しているが, 弚の值は属性値によっては， 最大值で約 20 \%という低いものもある.さらに，よい 学習器の構築のためには大きな学習用データセットを用 意する必要があり, 弚の作成の労力はやはり大きい.さ らに, 構造化したいデータのフォーマットは, 同じデー タでも記述される文脈，コミュニティ毎によって異なる ことがある，例えば，場所に関する情報の記述のされ方 は，イベントの開催地を表わす場合と誰かの住所を表わ す場合とで異なる可能性が高い . また，同一コミュニティ 内でも，時間が経過するにつれて情報の記述のされ方の フォーマットか変化する可能性がある . これらのパター ンやフォーマットの摇れの問題, 時間変化の問題には, こ れらのアプローチでは対応できない .

\section{3. 提 案 手 法}

我々が提案する手法では，情報抽出を複数段階に分け て行い, 情報抽出の各段階にユーザが投稿する情報や知 識を反映させる．情報抽出の全体の流れを图 1 に示す．

情報抽出を複数段階に分ける手法は，これまでも行わ れてきているが (例えば渡部ら [渡部 09])，本研究では 兴の各段階でユーザ入力を可能にする点が重要である．

情報抽出の各段階では必要とされる知識が異なるので， 各段階でユーザ入力を可能とすることで,さまざまなユー ザ参加方法を用意することが可能となる．多樣なユーザ 参加方法を用意することで，ユーザ参加に対するハード ルを下げ, 大多数のユーザから簡単に投稿できる知識を， 
表 1 ユーザ入カのタイプと投稿の例（属性タイプが日付のもの）

\begin{tabular}{|c|c|}
\hline 入力のタイプ & 投稿の例 \\
\hline $\begin{array}{l}\text { 選択 : } \\
\text { 教師データ }\end{array}$ & $\begin{array}{l}\text { イベント:2010 年 } 3 \text { 月 } 17 \text { 日 13:00- } \\
\text { 日時 : } 2010 \text { 年 } 3 \text { 月 } 1 \text { 日 (月) }\end{array}$ \\
\hline $\begin{array}{l}\text { 自由記述： } \\
\text { キーワード }\end{array}$ & $\begin{array}{l}\text { 開催日 : } \\
\text { に開催します。 }\end{array}$ \\
\hline $\begin{array}{l}\text { 自由記述： } \\
\text { 抽出ルール }\end{array}$ & 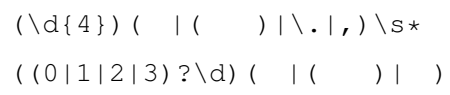 \\
\hline
\end{tabular}

そしてよりユーザ参加に積極的なユーザからはより複杂倠 で有用な知識を得ることができる．このように，ユーザ のモチベーションに合ったユーザ参加手法を用意してお くことで, ユーザの持つ知識を最大限活用することがで きるようになる .

機械学習の視点から本提案手法の利点は以下の通りで ある．まず，機械学習にユーザ知識を反映することで， ユーザ知識の信頼性を担保することができ，かつ再利用 性を高めることができるので, 効果的にユーザ知識をシ ステム全体の精度向上に貢献させることができる．機械 学習を通じてユーザ知識をシステムに反映することで， 間違ったユーザ知識やノイズデータを取り除くことがで きる . また , 個々の問題に対するユーザ投稿を, 分類器 の構築に反映することで, 全体の抽出精度の向上が期待 できる .

以下図 1 で示している情報抽出の流れについて説明す る . まず，情報抽出を対象とするドキュメントから抽出 したい情報の候補（以下，属性值候補と呼ぶ）を抽出す る.次に，得られた属性值候補を光れ光れ特徵ベクトル に変換する. 乥して, 機械学習によって構築した分類器 によって，これらの特徵べクトルが光れ光れ属性值，す なわち抽出したい情報であるかどうかを分類する . 最後 に, 分類器によって得られた分類結果に対して, ユーザ からの投稿情報を反映して最終的な表示結果を判定する .

この情報抽出の各段階に対して, ユーザはユーザ参加 を行うことができる . ユーザ参加の方法を大きく分ける と, 選択の問題と, 自由記述の問題に分けることができ るが, 本研究では光れ光れの問題を 2 つのレベルに分け， 合計 4 つのレベルのユーザ参加手法を用意した .すなわ ち，候補からの正誤情報選択問題，全体からの正誤情報 選択問題 , キーワードの自由記述問題 , 正規表現などの抽 出ルール自由記述問題である . これらのユーザ参加は乥 れぞれユーザに対する負荷や得られる情報の有用性にバ リエーションがあると考えられ，このように 4 つのレベ ルのユーザ参加手法を用意することで, 教師データ, キー ワード，抽出ルール弚れ光れについて，ユーザの自分の モチベーションに応じた入力が期待できる．表1に，今 回実装したシステムで投稿された日付情報の教師データ， キーワード，抽出ルールの例を示す．
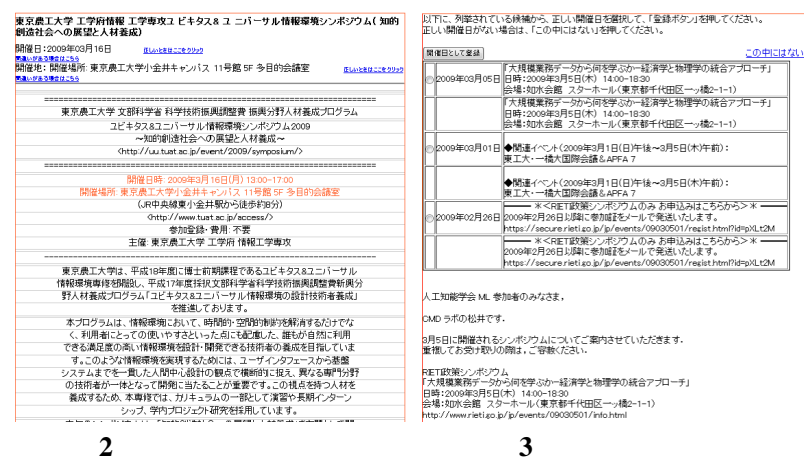

図 3 ユーザ投稿画面

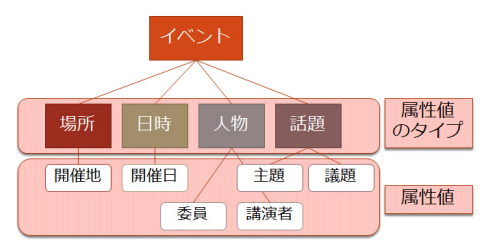

図 4 イベント情報の構造

\section{4. システム詳細}

本章では，提案手法を実装した「イベント情報構造化 システム」について説明する . イベント情報構造化シス テムは人工知能学会のメーリングリスト $* 3$ で告知される イベント情報を対象に，提案手法を実装した情報構造化 システムである . 抽出を行ったのはイベントのタイトル , 開催地と開催日の情報である . 图 2 にイベント詳細表示 画面の例を，図 3 に開催日情報の修正情報投稿画面の例 を示す．このシステムでは，イベントを開催日で検索し たり，近日中に行われるイベント一覧を表示することが できる．ユーザは，イベントを探す途中で抽出情報の間 違いに気づいた場合にはユーザ参加フォームから修正情 報や抽出ルールを投稿したりすることができる . タイト ル情報については，扱ったドキュメントの特性よりメー ルのタイトルをイベントのタイトルとした . 以下, 提案 手法をどのように実装したかについて説明する .

\section{$4 \cdot 1$ 対 象 問 題}

本稿では, メール文書からのイベント情報抽出という 問題を扱った . 対象としたメール文書は人工知能学会の メーリングリストであり，このメーリングリストで告知 される学会やシンポジウムの情報の構造化を行った .こ のメーリングリストを対象とした理由は，メーリングリ ストの管理者によってメールの内容が原稿募集なのかイ ベントの参加募集なのか，イベント開催日はいつなのか， といったタグが事前に付与されており，情報抽出システ ムによる情報抽出の精度計算を容易に行えることが挙げ られる . 問題設定は , メール文書のうち原稿募集および イベントの参加募集のものを対象に，テキストを改行文 字列で分割し，各行が抽出したいイベントに関する情報 を含んでいるか否かを判定する問題とした . 


\section{$4 \cdot 2$ 属性值候補の抽出}

図 4 に，抽出を行いたいイベント情報の構造の例を示 す．例えばイベント情報には場所情報や日時情報，人物 情報などが属性值のタイプとしてあり，光れ光れの下位 情報としてより具体的な，最終的に抽出を行いたい情報 が属性值として考えられる．例えば日時に関する情報と して開催日情報などがあり，人物に関する情報としては 委員情報や講演者情報などの複数の属性項目がある場合 もある.この段階では，日付情報などイベント情報の属 性值のタイプに当たる情報を属性值候補として抽出する 抽出ルールは正規表現にマッチするか否か，特定の単語 を含むか否かなど，光れ光れ抽出を行いたい属性値候補 に合った方法をとる．今回の実装では，日付情報の抽出 には，事前に用意した (50 件) もしくは投稿された正規 表現を各行に適用し，正規表現がマッチした行を属性值 候補とした．地名情報の抽出はすべての行を属性値候補 とした . ユーザか投稿した抽出ルールも属性值候補の抽 出に利用する。

\section{$4 \cdot 3$ 特徵ベクトルの作成}

ドキュメントから抽出されたそれ光れの属性值候補を 特徵ベクトルに変換する. 兴の変換ルールは以下の通り である .なお , 形態素解析にはフリーの形態素解析エン ジン $\left\ulcorner\mathrm{MeCab}{ }^{* 4}\right.$ を用いた . 特徵ベクトル次元の作成は， 山田らの手法を参考にしている [山田 02] .

1. 属性值候補の行と，本来のドキュメント中において その前にある行の末尾 3 文字と炎の後にある行の先頭 3 文字を結合し，文字列 $A$ を得る． $A$ をもとに，特徵べク トル a を作成する .

2. $A$ から得られる特徵ベクトル $\mathbf{a}$ は, 3 種類の特徵 ベクトル $\mathbf{w}, \mathbf{k}, \mathbf{r}$ から成り， $\mathbf{a}=\{\mathbf{w}, \mathbf{k}, \mathbf{r}\}$ であらわさ れる $. \mathbf{w}=\left(w_{1}, w_{2}, \ldots, w_{l}\right)$ は単語ベクトルで, $A$ が単語 $W_{i}$ を文字列内に含めば $w_{i}=1$ ，含まなければ $w_{i}=0$ と なる次元を持つベクトルである . 単語 $W_{i}$ はドキュメント 集合全体において 2 回以上出現する名詞のみに限定した . $\mathbf{k}=\left(k_{1}, k_{2}, \ldots, k_{m}\right)$ はキーワードベクトルで， $A$ が単語 $K_{i}$ を文字列内に含めば $k_{i}=1$, 含まなければ $k_{i}=0$ と なる次元を持つべクトルである . 単語 $K_{i}$ は事前に用意 したもの（開催日 24 件, 開催地 0 件) およびユーザが 投稿したものを用いた . $\mathbf{r}=\left(r_{1}, r_{2}, \ldots, r_{n}\right)$ は抽出ルール ベクトルで， $A$ に抽出ルール $R_{i}$ を適用し，マッチする もしくは真の值を返すならば $r_{i}=1$, マッチしないもし くは偽の值を返すならば $r_{i}=0$ となる次元を持つべクト ルである . 抽出ルール $R_{i}$ は開催日であれば事前に用意 した正規表現 50 件とユーザが投稿した正規表現，開催 地であれば事前に用意した抽出ルール 0 件とユーザが投 稿した抽出ルールを用いた .
表 2 実験 1，2，3 にて投稿されたユーザ情報の数

\begin{tabular}{lrrr}
\hline & 実験 1 & 実験 2 & 実験 3 \\
\hline 開催地の教師データ & 75 & 13 & 4 \\
開催地の抽出ルール & 0 & 0 & 0 \\
開催日の教師データ & 74 & 12 & 14 \\
開催日の抽出ルール & 3 & 0 & 0 \\
\hline
\end{tabular}

\section{4 分類器による判別と表示判定}

属性值候補から得られた特徵ベクトルを，機械学習で 作成した分類器によって乥れ午れ属性值であるか否か分 類する . 機械学習はサポートベクトルマシンを用いた . 分 類器の作成には，事前に用意した教師データ（開催日 150 件, 開催地 40 件) の他に, ユーザか投稿した正誤情報も 教師データとして利用する . 分類器によって得られた判 別結果とユーザからの投稿情報を用いて，さらに最終的 な表示判定を行う. ユーザからの投稿情報が一定数以上 ある場合には, 分類器から得た判別結果によらずユーザ からの投稿情報による多数決で表示判定を行い，一定数 に達しない場合は分類器から得た判別結果を最終表示に 用いる。

\section{5. 被 験 者 実 験}

\section{$5 \cdot 1$ 実 験 の 概 要}

本実験の目的は, ユーザから得た情報を機械学習を通 してシステムに反映することで情報抽出の精度がどのよ うに変化するのか, さまざまなユーザ参加を用意するこ とでユーザはどのようならるまいをし，ユーザへの負荷 はどのようになっているのか，を検証することである . 今 回は, 負荷や精度への影響において最も顕著な差が表れ ると思われる , 教師データと抽出ルールの投稿において 被験者実験を行った .

実験は，3 種類の実験とアンケートを 8 名の被験者に 遠隔でウェブブラウザ上で行ってもらった . 8 名の被験 者のうち，7 名は情報工学系の研究に従事しており，正 規表現やプログラミングの知識がある .8 名の内訳は学 部 4 年生 3 名, 大学院生 2 名, 研究者 3 名である .

実験 1 ではキーワード投稿を除く 6 種類のユーザ参加

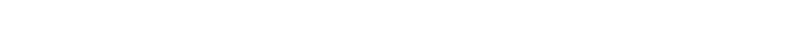
び投稿を行う問題を 5 題解いてもらつた . 実験 2 では自 由にシステムを操作してもらい，5つのデータに対して 6 種類のユーザ参加手法から自由に選んで投稿を行って もらつた . 実験 3 ではイベント検索のタスクを与え , タ スクをこなす途中で間違いを発見した場合に 6 つのユー ザ参加手法から自由に選んで投稿を行ってもらった . 実

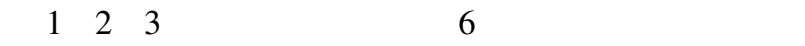
から得られたデータの数を表 2 に示す. 後の $5 \cdot 3$ 節でも 議論するが，実験 1，2，3 を通して得られた開催地，開 催日の抽出ルールのユーザ投稿件数は 0 件および 3 件と， 開催地, 開催日の教師データのユーザ投稿件数と比較し て少ない。 
表 3 開催地情報抽出の実験前後での抽出精度

\begin{tabular}{lrr}
\hline & 実験前 & 実験後 \\
\hline 問題数 (個) & 181 & 181 \\
提示数 (個) & 152 & 145 \\
正解数 (個) & 110 & 116 \\
再現率 (\%) & 60.77 & 64.09 \\
適合率 (\%) & 72.37 & 80.00 \\
F 値 & 66.07 & 71.17 \\
\hline
\end{tabular}

表 4 開催日情報抽出の実験前後での抽出精度

\begin{tabular}{lrr}
\hline & 実験前 & 実験後 \\
\hline 問題数 (個) & 574 & 574 \\
提示数 (個) & 583 & 586 \\
正解数 (個) & 103 & 117 \\
再現率 (\%) & 17.94 & 20.38 \\
適合率 (\%) & 17.67 & 19.97 \\
$\mathrm{~F}$ 值 & 17.80 & 20.17 \\
\hline
\end{tabular}

\section{$5 \cdot 2$ ユーザ参加の効果}

ユーザ知識による精度の向上について, 実験で得られ たデータを教師データ, 特徵ベクトル作成ルールとして 追加して学習器を再構築し, 追加の前後て情報抽出の精 度を計算したものを表 3 , 表 4 に示す. 追加したデータ は，実験で得られたデータから同じ問題に対する投稿の 重複分を除いた，開催地情報の教師データ 31 件，開催日 情報の教師データ 31 件, 開催地情報の特徵ベクトル作成 ルール 0 件, 開催日情報の特徵ベクトル作成ルール 3 件 である.評価には，再現率，適合率および $\mathrm{F}$ 值を用いた 。 表 3 , 表 4 より, 開催地, 開催日どちらの抽出において も，再現率，適合率， $\mathrm{F}$ 值全ての值がデータ追加前より もデータ追加後において高いことが分かる .このことよ り，開催地，開催日いずれも，ユーザ知識を追加するこ とで情報抽出精度は向上したといえる . 開催日の抽出精 度か開催地の抽出精度に比へてて低いことについて，日付 情報には開催日以外にも参加申込締切日や投稿締切日な どの情報も存在することが影響していると考えられる．

次に，開催日情報の抽出において教師データ，特徵べ クトル作成ルールを光れ別々に追加した場合の情報 抽出精度の結果を表 5 に示す. この表より, 教師データ のみを追加した場合, 特徵べクトル作成ルールのみを追 加した場合でも，追加しなかった場合に比べて情報抽出 精度は上がっていることが分かる.しかし, 両方追加し た場合の抽出精度が最も高くなっていることから，教師 データの投稿，特徵ベクトル作成ルールの投稿どちらも 抽出精度の向上に貢献するが，両方追加した場合が最も 抽出精度の向上が大きく，どちらのデータもユーザから 収集する必要性が示されたといえる．また，表 5 より追加 データの F 值の平均上昇量を計算すると，教師データに ついては (18.96-17.80)/31=0.04, 特徵ベクトル作成ルー ルについては (18.32-17.80)/3=0.17 となる.データ 1 件
当たりの情報抽出精度への貢献は教師データよりも特徵 ベクトル作成ルールのほうが大きいと考えられる .

\section{$5 \cdot 3$ ユーザ参加の負荷}

次に, ユーザへの負荷とユーザ参加の動機について，ア ンケートの結果を用いて考察する . 開催日のキーワード 投稿を除く 6 種類のユーザ参加手法について，問題画面 を示してからユーザが投稿情報を選択して投稿を行うま での平均所要時間 , ユーザ参加の負担について「大きな 負担だった」「やや大きな負担だった」「どちらとも言え ない」「あまり大きな負担ではなかった」「大きな負担で はなかった」の 5 段階評価で質問したうち，負荷が大き いという「大きな負担だった」「やや大きな負担だった」 の 2 つの回答の合計割合を表 6 に示す .

表 6 より，開催地 , 開催日どちらにおいても，投稿まで の平均所要時間，負荷が大きいという回答の割合关れ光 れの值について, 小さいものから，候補からの選択，メー ル全体からの選択，プログラムコードや正規表現などの 抽出ルールの投稿，となっている．これより開催日情報， 開催地情報光れ光れについて，ユーザ参加の負荷の大き さは, 小さい順から候補からの選択 , メール全体からの 選択 , プログラムコードや正規表現などの抽出ルールの 投稿，となっていると考えられる．また，表 6 より抽出 ルールの投稿の負荷は他のユーザ参加に比べて極めて大 きく，このことがユーザ参加の件数が少ない原因となっ ていると考えられる.しかし，5·2節で示したように，抽 出ルールの方が教師データよりもデータ 1 件当たりの抽 出精度への貢献は大きい . システムの寄与に関する適切 なフィードバックがユーザに与えられれば，ユーザは負 担感と貢献度のトレードオフで自分にとって適切な参加 方式を選んで参加することができるといえる .

\section{6. おわりに}

本稿では，機械学習と集合知を組み合わせることで多 樣なユーザ参加手法を実現する情報抽出手法を提案し， 学会イベント情報を対象に教師データ, キーワード，抽出 ルールを投稿できるイベント情報の構造化システムを実 装した . 教師データ，抽出ルールについて被験者実験を 行い, 複数のユーザ参加方法を用意することの有効性と， 異なる知識レベルのユーザ知識を反映することで，弚の

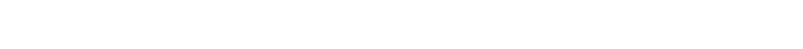
上することを確認した .

今後の課題としては, 開催日情報や開催地情報以外の 抽出, 人工知能学会のメーリングリスト以外のドキュメ ントへのシステムの適用 , 教師データ , 抽出ルールなど のユーザ参加方法の一層の多樣化，精度向上に寄与の大 きいユーザ知識を，低い負荷で投稿できる方法の実現な どがある .

今回試みた機械学習とユーザ参加の組み合わせによる システム構築というアプローチには樣々な可能性がある 
表 5 開催日情報抽出における, 追加データの種類と精度向上

\begin{tabular}{|c|c|c|c|c|}
\hline & 追加な & 教師デー & ルール & 両方追 \\
\hline & し (実 & タのみ追 & のみ追 & 加 (31 \\
\hline & 験前) & 加 (31 件) & 加 (3 件) & +3 件) \\
\hline 問題数 (個) & 574 & 574 & 574 & 574 \\
\hline 提示数 (個) & 583 & 586 & 583 & 586 \\
\hline 正解数 (個) & 103 & 110 & 106 & 117 \\
\hline 再現率 (\%) & 17.94 & 19.16 & 18.46 & 20.38 \\
\hline 適合率 (\%) & 17.67 & 18.77 & 18.18 & 19.97 \\
\hline $\mathrm{F}$ 值 & 17.80 & 18.96 & 18.32 & 20.17 \\
\hline
\end{tabular}

と考えている．例えばタグや文章より細かいシステムレ ベルの知識の集約といった状況や特定の知識をもつたユー ザの集合知といった状況では，これまでにない効果が期 待できると思われる .

\section{謝辞}

本研究で用いたメールデータは,「人工知能学会からの お知らせメーリングリスト」を管理・運営されている神 嶌敏弘氏からお借りしました .ご協力に感謝致します．

\section{$\diamond$ 参 考 文 献 $\diamond$}

[Mika 05] Mika, P.: Ontologies Are Us:A Unified Model of Social Networks and Semantics, ISWC 2005 (2005)

[O'REILLY 05] O'REILLY, T.: What Is Web 2.0-Design Patterns and Business Models for the Next Generation of Software, http://www.oreillynet.com/pub/a/oreilly/tim/news/2005/09/30/whatis-web-20.html (2005)

[Surowiecki 05] Surowiecki, J.: The Wisdom of Crowds, Anchor (2005), (邦訳 : ジェームズ・スロウィッキー, 小高尚子 (訳),「み んなの意見」は案外正しい, 角川書店)

[Xin 08] Xin, X., Juanzi, L., Jie, T., and Qiong, L.: Academic conference homepage understanding using constrained hierarchical conditional random fields, in CIKM '08, pp. 1301-1310 (2008)

[関根 99] 関根 聡 : テキストからの情報抽出 : 文書から特定の情 報を抜き出す, 情報処理, Vol. 40, pp. 370-373 (1999)

[吉谷 04] 吉谷 仁志, 黄瀬 浩一, 松本 啓之亮 : サポートベクトルマ シンを用いたプロフィール情報の抽出, 情報処理学会研究報告. 自然言語処理研究会報告, Vol. 2004, pp. 7-12 (2004)

[後藤 10] 後藤 真孝, 緒方 淳, 江渡 浩一郎 : PodCastle: ユーザ貢献 により性能が向上する音声情報検索システム, 人工知能学会論文 誌, Vol. 25, pp. 104-113 (2010)

[佐藤 95] 佐藤 円, 佐藤 理史, 篠田 陽一: 電子ニュースのダイジェ ス卜自動生成, 情報処理学会論文誌, Vol. 36, pp. 2371-2379(1995) [三宅 02] 三宅 新二, 岡部一光, 鳥越 秀知, 横田 一正 : HTML 文 書からのイベント情報抽出, 情報処理学会研究報告. データベー ス・システム研究会報告, Vol. 2002, pp. 31-38 (2002)

[山田 02] 山田 寛康, 工藤 拓, 松本 裕治 : Support Vector Machine を用いた日本語固有表現抽出, 情報処理学会論文誌, Vol. 43, pp. 44-53 (2002)

[渡部 09] 渡部 啓吾, Bollegala, D., 松尾 豊, 石塚 満 : Web からの 人物の属性情報抽出, 第 23 回人工知能学会全国大会 (JSAI2009) 論文集 (2009)

〔担当委員 : 古川 忠延〕
表 6 回答平均所要時間, 負荷の大きさに関するアンケート結果

\begin{tabular}{l|c|c}
\hline ユーザ参加の種類 & $\begin{array}{c}\text { 回答平均所 } \\
\text { 要時間 (秒) }\end{array}$ & $\begin{array}{c}\text { 負担が大きいややや大き } \\
\text { いの回答の割合 (\%) }\end{array}$ \\
\hline 開催地 : & & 28.6 \\
候補の中からの選択 & 11.3 & 42.8 \\
文書全体からの選択 & 14.3 & 85.7 \\
プログラムコードの投稿 & 189.8 & \\
\hline 開催日 : & & 28.6 \\
候補の中からの選択 & 24.9 & 42.8 \\
文書全体からの選択 & 31.5 & 85.7 \\
正規表現の投稿 & 132 & \\
\hline
\end{tabular}

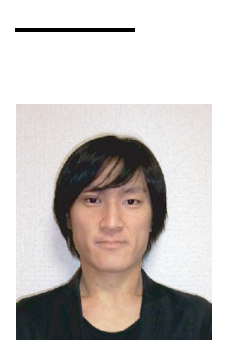

\section{紹 介}

\section{森近 憲行}

1988 年山口県生まれ.2010 年東京大学工学部卒業、現 在, 同大学院工学系研究科修士課程に在籍. 情報抽出など の Web マイニング, および弚れを利用した推薦システム に興味がある。

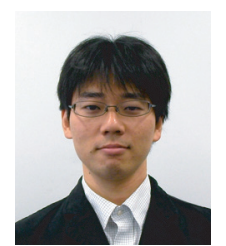

濱崎 雅弘 (正会員)

2000 年同志社大学工学部知識工学科卒業. 2002 年奈良先 端科学技術大学院大学情報科学研究科博士前期課程修了。 2005 年総合研究大学院大学複合科学研究科博士後期課程 修了. 博士 (情報学) . 同年より, 産業技術総合研究所情 報技術研究部門勤務 . 情報推薦やオンラインコミュニティ の研究に従事 .人のネットワークを活用した情報システム に興味がある。電子情報通信学会, 日本知能情報ファジィ 学会, $\mathrm{ACM}$, 各会員.

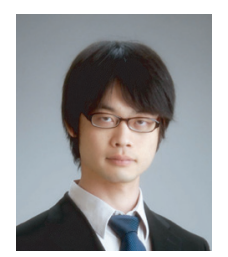

\section{亀田 克宙 (正会員)}

1984 年京都生まれ. 2007 年東京大学工学部卒業. 2009 年 東京大学大学院新領域創成科学研究科修士課程修了. 修士 (環境学). 現在, 同大学院情報理工学系研究科博士課程在 籍. 人と情報のインタラクションで築かれる信頼, 弚れに 基づく情報推薦に興味がある。

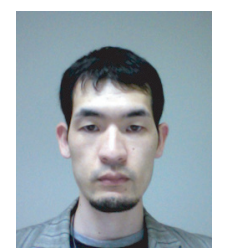

\section{大向 一輝(正会員)}

1977 年京都生まれ. 2000 年同志社大学工学部卒業 . 2005 年総合研究大学院大学複合科学研究科博士課程修了. 博士 (情報学). 同年国立情報学研究所助手, 2007 年同助教, 2009 年同准教授. 2010 年総合研究大学院大学准教授 (併 任）．セマンティックウェブやソーシャルウェブに関する 研究開発に従事. 情報処理学会会員.

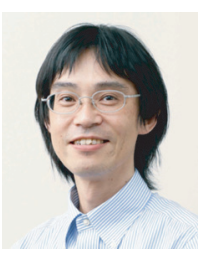

武田 英明(正会員)

1986 年 3 月東京大学工学部卒業. 1988 年 3 月同大学院 工学系研究科修士課程修了. 1991 年 3 月同博士課程修了。 工学博士 .ノルウエ一工科大学, 奈良先端科学技術大学院 大学を経て, 2000 年 4 月から国立情報学研究所助教授、 2003 年 5 月同教授. 2006 年 4 月同学術コンテンツサー ビス研究開発センター長 (併任). 2005 年 12 月 2010 年 3 月東京大学人工物工学研究センター客員教授、特任 教授、知識共有, Web 情報学, 設計学等の研究に従事. 情 報処理学会, 電子情報通信学会, 精密工学会, AAAI 各会員。 